Canadian

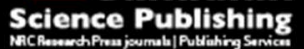

Canadian Journal of Civil Engineering Revue canadienne de génie civil

\title{
Correction of air freezing index for pavement frost protection design to consider future climate changes
}

\begin{tabular}{|r|l|}
\hline Journal: & Canadian Journal of Civil Engineering \\
\hline Manuscript ID & cjce-2015-0475.R1 \\
\hline Manuscript Type: & Article \\
\hline Date Submitted by the Author: & $15-J a n-2016$ \\
\hline Complete List of Authors: & $\begin{array}{l}\text { Bilodeau, Jean-Pascal; Laval University, Department of civil engineering } \\
\text { Doré, Guy; Laval University, Department of civil engineering } \\
\text { Perron Drolet, François; Englobe } \\
\text { Chaumont, Diane; Ouranos }\end{array}$ \\
\hline Keyword: & $\begin{array}{l}\text { Climate change, air freezing index, flexible pavements, roughness, frost } \\
\text { heave }\end{array}$ \\
\hline &
\end{tabular}

SCHOLARONE

Manuscripts 
Correction of air freezing index for pavement frost protection design to consider future climate changes

\section{Corresponding author}

Jean-Pascal Bilodeau

Department of civil engineering

Laval University

1065 avenue de la Médecine

Québec, Canada

G1V $0 A 6$

418-656-2131 \#7242

jean-pascal.bilodeau@gci.ulaval.ca

Guy Doré

Department of civil engineering

Laval University

1065 avenue de la Médecine

Québec, Canada

G1V $0 A 6$

418-656-2203

guy.dore@gci.ulaval.ca

François Perron Drolet

Englobe

325, rue de l'Espinay

Québec, Canada

G1L 2J2

T 418.647-1402

francois.drolet@englobecorp.com

Diane Chaumont

Ouranos

550, Sherbrooke Ouest

Tour Ouest, 19e étage

Montréal, Québec

H3A 1 B9

Tél. : 514 282-6464

Chaumont.Diane@ouranos.ca

Word count : 8354 
Abstract : In cold regions, climate affects flexible pavement performance, such as frost heave. In the context of a changing climate, air freezing index can no longer be considered as fixed for pavement design. Climate simulations were performed for Quebec conditions in order to determine the evolution of the air freezing index over the coming decades. Using a relationship between average frost heave and the yearly roughness deterioration rate and a proposed method to consider decreasing air freezing index, the effect of climate change was quantified with respect to the $1971-2000$ conditions. Thinner pavement structures are obtained with the calculation approach, and its effect was quantified in terms of materials and pavement life. It was shown that a reduction of $100 \mathrm{~mm}$ could be considered for pavements built on frost sensitive soils. In addition, the proposed method showed an increase of pavement life, quantified with roughness, for most of the cases considered.

Keywords : Climate change, air freezing index, flexible pavements, roughness, frost heave 


\section{Introduction}

In the past few decades, signs of an evolving climate were discussed among the scientific community. While a couple of years ago, the subject of climate changes did not make a full consensus, it is now difficult to deny the various proofs of climate change around the globe (IPCC 2013). The obvious changes in climate are usually associated with the beginning of the industrial era. This period is characterized by a massive increase in emissions of greenhouse gases such as $\mathrm{CO}_{2}, \mathrm{CH}_{4}$ and $\mathrm{NO}_{2}$. Indeed, the warming observed from the mid- $20^{\text {th }}$ century is unequivocal and IPCC (2013) states that it is extremely likely that human influence is the dominant cause of that warming. Climate change also manifest as increases in ocean temperatures, an increase of sea level and a decrease of sea ice extent. Global warming also affects frozen ground, as permafrost temperature increases of up to $3^{\circ} \mathrm{C}$ in parts of Northern Alaska between the mid-1980s and mid-2000s were documented (IPCC 2013). Moreover, nonuniform changing pattern regarding the precipitation regimes were observed all over the globe (IPCC 2013). The work of Collins et al. (2013) states that warming is likely to continue over the $21^{\text {st }}$ century if greenhouse emissions associated with human activity continue to rise. The projected increase by the end of the century is expected to reach 1.8 to $3.8^{\circ} \mathrm{C}$ depending on the emission trend considered. The warming may, however, not be uniform all over the globe (Maloney et al. 2014), with greater changes expected at higher latitudes.

When it comes to pavement performance, the temperature is among the most influential factors associated with climate to consider (Byram et al. 2012), and its variation is among the most probable climate variations for future climates (Emery 2010). Climate change is likely to influence pavement performance and response in many ways., The main manifestations of its 
effect are rutting, longitudinal cracking, fatigue cracking, transverse cracking or roughness (Tighe et al. 2008; Kim et al. 2005; Graves et al. 2006; Dawson 2010; Carrera et al. 2009). In North America, climate changes are expected to be more significant during the winter period (Desjarlais et al. 2010; Thiam 2014; Perron Drolet 2015; Emery 2010). Increase of temperature, precipitation and number of winter partial thaws is the effect of climate change expected to occur in the winter period (Chaumont and Brown 2010; Logan et al. 2011). Moreover, climate change will also have a significant effect on the length of the freezing season (decrease) or even on the number of days to reach a critical freezing index (increase) (Mills et al. 2009). The research work of Logan et al. (2011), Emery (2010), Dawson (2010) and Chaumont and Brown (2010) showed that future climate conditions will likely be associated with more frequent freeze-thaw cycles during the winter period.

For many types of engineering projects, climate is an important factor to take into consideration in order to ensure a long-lasting performance. This is the case in pavement engineering, where many climatic data, such as temperatures and moisture, are considered when designing pavement structures (NCHRP 2004; Huang 2004; TAC 1997). In northern countries, air temperature is essential to quantify the length and severity of the winter period. This is usually done using the air-freezing index $\mathrm{Fl}_{\mathrm{a}}$ which, expressed in ${ }^{\circ} \mathrm{C}^{*}$ day, represents the sum of the average daily temperatures throughout the sub-zero time period, or the average temperature of the freezing period multiplied by the length of the freezing period (Doré and Zubeck 2009). Many design methods use this parameter for frost protection of pavement structures. The frost protection principles are usually based on the limitation of frost action in the most frost sensitive component of the pavement system, the subgrade soil. Frost heaving problems are likely to occur if the subgrade is frost sensitive and if water is available in the system; soils are 
considered to have low sensitivity to frost action if the degree of saturation is below $70 \%$ (Konrad and Roy 2000). The thickening of the pavement structure is the most common way to protect the subgrade against frost action. Frost penetration is then be affected by the thermal properties of the pavement materials, which are influenced by mineralogy, water content and density among other things (Kersten 1949; Côté and Konrad 2005). When severe frost heaving and/or significant differential frost heaving are anticipated, pavement insulation is an interesting solutions to counter frost action and to prevent heat loss in the pavement system (Doré and Zubeck 2009). Extruded (most common) or expanded polystyrene, lightweight concrete or lightweight aggregate, wood residues and peat, are the most common materials used in pavement insulation layers. When designing an insulated pavement, the designer must take into account the low stiffness of the insulation layer, its thermal effectiveness, the risk of differential icing at the pavement surface and thedifferential behaviour at the end of the insulated areas.

In Quebec, frost protection design method is an important part of the flexible pavement design procedure. Two alternatives are offered in the pavement design method proposed by the Quebec Ministry of Transportation. The first is a minimum thickness design used to ensure that adequate partial protection against frost is obtained through the use of an empirical criterion (Saint-Laurent 2006; Saint-Laurent 2012; Armstrong and Csathy 1963). This empirical criterion, adapted for the context of Quebec Province, suggests the minimum thickness of the pavement as a function of the normal $F I_{\mathrm{a}}$ and other considerations such as pavement functional class and subgrade soil. The empirical partial frost protection allows to determine a pavement structure thickness based on the experience in Canada which suggests that the pavement performance against frost is generally acceptable when a thickness protection corresponding to $50 \%$ of the 
typical frost depth is used. The second approach is a mechanistic-empirical design procedure for frost protection that uses the Saarelainen-Konrad method to calculate frost penetration and associated frost heave at a daily time step using iterative calculations (Saarelainen 1992; SaintLaurent 2012; Saarelainen 1992). At each time step, the heat balance at the frost front and the associated frost heave are calculated. The basic thermal balance equation is defined by

[1]

$$
\mathrm{q}_{-}=\mathrm{q}_{+}+\mathrm{q}_{\mathrm{f}}+\mathrm{q}_{\mathrm{s}}
$$

in which $q_{\text {- }}$ is the heat flux from the frost front towards the surface through the frozen layer, $q_{+}$ is the geothermal heat flux, $q_{\mathrm{f}}$ is the heat flux generated by the phase change from water to ice and $q_{\mathrm{s}}$ is the additional heat flux induced in the system by the freezing of water that migrates upward due to cryosuction and which feeds the growing ice lenses. Solving this heat balance thermal equation gives the frost penetration at each time step. After each iteration, the frost heave associated with the freezing of a given sublayer is calculated considering the $9 \%$ volume increase of water when changing to ice, as well as the heave induced by ice segregation. The latter is obtained from frost heave mechanics theory (Konrad and Roy 2000; Konrad and Morgernstern 1981) and is expressed as

$$
\mathrm{dh}=1.09 \times \mathrm{SP} \times \mathrm{GradT}_{-} \times \mathrm{dt}
$$

in which $d h$ is the frost heave of a sublayer, $S P$ is the segregation potential, GradT. is the thermal gradient of the frozen soil at the segregation front and $d t$ is the time interval. The frost heave calculated for a given winter is then compared to the allowable frost heave, which have been determined based on previous field performance observations. The Finnish Road Administration 
and the Quebec Ministry of Transportation are among the few agencies proposing allowable frost heave criteria (Doré and Zubeck 2009; Saint-Laurent 2006; Saint-Laurent 2012; Tammirinne et al. 2006), mostly ranging from 30 to $100 \mathrm{~mm}$ depending on road functional class. The Saarelainen-Konrad calculation method requires many thermal parameters for the pavement soils and materials, such as heat capacity, thermal conductivity and latent heat. One of the main parameters needed for thermal calculations is the thermal boundary condition at the pavement surface, which is the surface freezing index $F I_{s}$. This input parameter can be obtained directly from the $\mathrm{Fl}_{\mathrm{a}}$ using the n-factor simplified approach (Andersland and Ladanyi 2004; Ladanyi 1996; Doré and Zubeck 2009). Therefore, the $\mathrm{Fl}_{\mathrm{a}}$ is of great importance for pavement design in northern countries where undesirable effects, such as differential frost heave, associated with frost action are likely to occur (Bilodeau and Doré 2013; Doré 1997; Doré and Zubeck 2009).

As air temperatures, and thus the $\mathrm{Fl}_{\mathrm{a}}$, have a strong influence on pavement performance during the winter period, a question then arises of how to take future winter climate changes into consideration for the determination of this design parameter. The following sections present a method that takes into account climate changes as part of pavement design for frost protection.

\section{Climatic simulations}

Climate change predictions were performed by Ouranos, a consortium which specializes in climate science research, to assess the evolution of the air-freezing index $\left(F l_{\mathrm{a}}\right)$ with respect to to a reference period, which was set from 1971 to 2000 . The simulations performed consist of a group of future climate determinations based on various climatic scenarios. A climatic scenario 
consists of a choice of tools (climatic models), simulation methods, variables, regions, periods, frequency of analysis, statistical approach, etc. In this project, the use of delta climatic simulations was selected to partly eliminate some bias associated with the imperfections of climatic simulations. The effects of increasing greenhouse gases are predicted in different scenarios throughout the literature using various assumptions on demography, technology, economics, politics, etc. The magnitude of the expected climate change is directly associated with the particular scenario, which can vary from optimistic (low magnitude climate change) to pessimistic (high magnitude climate change). The work from Nakicenovic et al. (2000) and IPCC (2007) analyzes the effect of various scenarios of increasing greenhouse gases on global surface warming. The selected scenario A1B approximately represents the statistical median, in terms of global surface warming, of the scenarios initially considered, and is used in this paper to simulate the evolution of greenhouse emissions over the next few decades. However, prior to 2050 , the effect of increasing greenhouse gases is limited to global surface warming. In order to adequately incorporate natural climate variability in climate modelling for future periods, five members of the Canadian Global Circulation Model (CCMA_CGCM version 3.1), as well as one member of the German model (SCIRO version mk 3.5) and one member of the Australian model (MPI_ECHAM version 5), were used in the analysis.

The simulations were performed and the averages for over 30 years periods were calculated in order to minimize bias and annual variability, as previously described. This period length is considered sufficient to include in the analysis a significant number of abnormal conditions, such as atypically mild winters, the important quantity of liquid precipitations during the winter period, etc. In order to simulate the expected climate for various time horizons, the following 
periods were selected for climatic modelling: 2001-2030, 2011-2040, 2021-2050, 2031-2060, 2041-2070 and 2051-2080. Depending on various parameters, such as proximity of the sea, altitude, latitude, dominant winds, the climate change predictions are likely to differ depending on the geographical position in the province of Quebec. Therefore, as presented in Figure 1, the southern part of the Quebec map was divided into 3 different zones, all characterized by an expected evolution of the climate. This division was based on three different documents. The first document was the map used by the Quebec Ministry of Transportation to define three distinct spring load restriction zones. This map shows a division of Quebec's territory with respect to the period of the year during which spring thaw occurs (https://www.mtq.gouv.qc.ca/usagers/vehiculelourd/degel/Pages/Zones-de-

d\%C3\%A9gel.aspx). The second document is the map of the historical air-freezing index over Quebec's territory, currently used for flexible pavement design at MTQ. This map clearly shows a northwest-southeast gradient of the index over the province, and a northeast-southwest gradient with respect to the St-Lawrence River (Ladanyi 1996). The third document was based on the study of Chaumont and Brown (2010) that presented a map of air-freezing index variations for the period 2041-2070 with respect to the period 1971-2000. The combination of the three documents allowed obtaining the climatic zone divisions considered for this study as presented in Figure 1.

Figure 2 presents the evolution of the variation of $F I_{a}\left(\Delta F I_{a}\right)$ from the reference period as a function of the climatic horizon considered for the median scenario. The decreasing rate of $\Delta F I_{a}$ with respect to time varies between -7.6 and $-9.7{ }^{\circ} \mathrm{C}^{*} \mathrm{~d}^{*} \mathrm{yr} \mathrm{r}^{-1}$. Table 1 presents the decreasing rates of $\Delta F I_{\mathrm{a}}$ with respect to time for the median scenario. The variation of the air freezing index 
is similar in zone 1 and zone 2, but the northern zone (zone 3 ) is more likely to be subjected to more significant climate changes during winter, as proposed by Desjarlais et al. (2010).

\section{Effect of decreasing $F I_{a}$ with climatic horizon}

The evolving $\mathrm{Fl}_{\mathrm{a}}$ was used as an input for pavement design for the purpose of this project. The flexible pavement design software used in Quebec, CHAUSSEE 2, allows structural calculations using the AASHTO empirical method (AASHTO 1993) and uses the combined Saarelainen-Konrad method to calculate frost penetration and corresponding frost heave with an iterative thermal balance calculation at the frost front. A minimum frost protection is also ensured using an empirical criteria. First, the software was used to calculate a reference structure for the year 2010. The $F l_{\mathrm{a}}$ was adjusted for the year 2010 using the $F I_{\mathrm{a}}$ of each zone and the decreasing rates $\Delta \mathrm{Fl}_{\mathrm{a}}$. The $1971-2000 \mathrm{Fl}_{\mathrm{a}}$ values are 1070,1240 and $2004{ }^{\circ} \mathrm{C}^{*} \mathrm{~d}$ and the corresponding $2010 \mathrm{Fl}_{\mathrm{a}}$ values are 992,1158 and $1907^{\circ} \mathrm{C} * \mathrm{~d}$, for zones 1,2 and 3, respectively. In order to cover a wide range of likely situations representative of the Quebec conditions, three pavement functional classes (national, regional and local) and three type of soils (Low plasticity clay - CL, Silty sand SM and Silty/Clayey gravel - GC-GM) were considered for each zone, as presented in Table 2 and Table 3. Table 2 presents the main characteristics of each pavement class, while the main soil parameters used as inputs in the design method are presented in Table 3. The following are found among the data presented in Table 3: the effective resilient modulus (Mreff), the segregation potential for the no vertical stress condition $\left(S P_{0}\right)$, the coefficient of sensitivity to vertical stress for the segregation potential $(a)$, the dry density $\left(\rho_{\mathrm{d}}\right)$, the frozen thermal conductivity $\left(k_{f}\right)$, the degree of saturation $(S r)$ and the latent heat of fusion for the soil $\left(L_{f}\right)$. Table 
4 presents the structures obtained by the combined optimization process for the frost protection and structural design. It should be noted that Quebec specifications impose a minimum layer thickness for each pavement layer. When required, the design software imposed the minimum thickness. It can be observed that for a given pavement functional class, the thickness of the asphalt concrete layer and of the granular base are the same or very similar. In each case, only the subbase thickness varies significantly with the $F l_{a}$, soil type and functional class, due to the requirements for frost protection.

Since, as mentioned previously, the climate is evolving for the simulations presented in this paper, the pavement response to climatic conditions should also evolve with the climate. Doré and Zubeck (2009) presented an empirical relationship based on the work from Doré (1997, 2002) for the experience in Quebec that links the yearly increase rate of pavement roughness to the average frost heave encountered on a yearly basis $h(\mathrm{~mm})$. This relationship is expressed as

$$
\Delta \mathrm{IRI}=0.0017 \mathrm{~h}+0.0297
$$

in which $\Delta I R I$ is the yearly increase rate of the International Roughness Index $(I R I)$ in $\mathrm{m} \mathrm{km}^{-1} \mathrm{yr}^{-1}$. Using Equation 3, average frost heave values of about 40 to $80 \mathrm{~mm}$ will lead to a yearly $I R I$ increase rate of about 0.1 to $0.15 \mathrm{~m} \mathrm{~km}^{-1} \mathrm{yr}^{-1}$. For example, a terminal $I R I$ condition of $2.5 \mathrm{~m} \mathrm{~km}^{-}$ ${ }^{1}$, corresponds to a pavement at the end of its service life. Acceptable frost heave of 30 to 60 mm (Konrad 1998, cited in Saint-Laurent 2012), 30 to $100 \mathrm{~mm}$ (Gustavsson et al. (1999) and lower than $50 \mathrm{~mm}$ (Saint-Laurent 2012) were reported to be associated with adequate pavement performance depending on the pavement functional class. Therefore the associated pavement service life for this range of frost heave over typical values of the $I R I$ terminal 
condition implies that the empirical equation provides an approximate but realistic estimate of the annual rate of increase of the International Roughness Index.

As pavement performance is associated with frost heave, CHAUSSEE 2 (Saint-Laurent 2006; Saint-Laurent 2012) was used to compute the frost penetration and the corresponding frost heave during the years 2010 to 2050 . With the calculated frost heave, a $\Delta I R I$ value was obtained for each year of the analysis period. Figure 3 presents the calculated frost penetration $(X)$, frost heave $(h)$ and $\Delta I R I$ with respect to time for the $C L$ soil example. It can be observed that the decreasing $\mathrm{Fl}_{\mathrm{a}}$ is associated with decreasing frost penetration, frost heave and $\Delta / R I$. This information is noteworthy, as it implies that the effect of climate change will likely cause an overdesign of flexible pavement structures against frost action over time. This is explained by the fact that the pavement design process is usually based on historical climatic conditions, which are likely to evolve from the moment the pavement is built.

\subsection{Adjusted air freezing index}

Because of the evolving climate, it was proposed to modify the design $F_{\mathrm{a}}$ to take into account the future climate changes that will likely occur during the selected design period, which is a function of the pavement classification. As the design year $\mathrm{Fl}_{\mathrm{a}}$ may not be representative of the average climatic conditions that will likely occur during the design period $n$, an adjusted $F I_{a}$, identified as $\mathrm{Fl}_{\mathrm{a} \text {-adj, }}$ was proposed. This value of $\mathrm{Fl}_{\mathrm{a} \text {-adj }}$ is the $\mathrm{Fl}_{\mathrm{a}}$ that occurs in the middle of the design period $(n / 2)$. It is expressed as 
[4]

$$
\begin{aligned}
& \mathrm{FI}_{\mathrm{a}-\mathrm{adj}}=\mathrm{FI}_{\mathrm{a}-\mathrm{ref}}-\Delta \mathrm{FI}_{\mathrm{a}} \\
& \Delta \mathrm{FI}_{\mathrm{a}}=\frac{\left(\mathrm{Y}_{\mathrm{ini}}-\mathrm{Y}_{\mathrm{ref}}\right)}{\mathrm{m}}+\frac{\mathrm{n} \times \mathrm{m}}{2}
\end{aligned}
$$

in which $F I_{\mathrm{a}-\mathrm{ref}}$ is the air freezing index of the reference period, $\Delta F I_{\mathrm{a}}$ is the variation of the air freezing index, $Y_{\text {ini }}$ is the design year, $Y_{\text {ref }}$ is the reference year, $n$ is the design period and $m$ is the slope of the variation of $\mathrm{Fl}_{\mathrm{a}}$ with respect to time. Figure 4 presents the calculation and the approach proposed to calculate $F l_{\text {a-adj }}$. This adjustment method for the air freezing index was used to determine a new pavement design using the $F l_{\text {a-adj }}$ as an input for the design procedure. This is likely to reduce the thickness of the frost protection layer for some of the cases considered.

\subsection{Assessment of the economy of granular materials}

Table 5 presents the comparison of the response of the pavement structures regarding frost heave $h$ for the case where the standard $F l_{\mathrm{a}}$ is used and for the case where the $F I_{\mathrm{a} \text {-adj }}$ is used. As a reminder, $F l_{\mathrm{a}}$ is the air-freezing index used in the reference period and $F I_{\mathrm{a} \text {-adj }}$ is the adjusted airfreezing index, which occurs in the middle of the design period, calculated using the procedure introduced in Equation 2. The comparison is made on the basis of the obtained frost heave $h$ and the average frost heave $h_{\mathrm{av}}$, which are calculated using the Saarelainen-Konrad method. The $h$ value is calculated with a reference freezing-index $F l_{a}$, which is fixed at the beginning of the design period. The use of a lower air freezing index $\left(F I_{\text {a-adj }}\right)$ when the adjustment method is used implies that a lower frost heave is likely to be encountered. In that case, the frost heave is identified as the average frost heave that occurs throughout the pavement life $h_{\mathrm{av}}$. Therefore, 
through the design procedure that uses $F l_{\mathrm{a} \text {-adj }}$, the thickness of the subbase $D_{\mathrm{sb}}$ can be modified to meet the allowable frost heave for a given pavement functional class. As a result, when using $F l_{\text {a-adj, }}$ there may be a variation in the subbase thickness $\Delta D_{\mathrm{sb}}$, and corresponding cost savings in terms of granular materials. These savings are based on average material costs considered for a preliminary design at the Ministry of Transportation of Quebec. The results presented in Table 5 show that significant savings can be obtained for pavements built on frost susceptible soils. In the case of pavements built on clayey subgrade soil, the thickness of the subgrade layer can decrease by approximately $100 \mathrm{~mm}$ for all the climatic zones and pavement classes. The corresponding average savings in materials is about $0.9 \$ \mathrm{~m}^{-2}$. For the other soil types less sensitive to frost action, it is generally observed that no cost savings are achieved because the frost heave is always below the allowable limit for each pavement functional class. The thickness of the subbase in these cases is fixed at a minimum value of $300 \mathrm{~mm}$ according to the requirements of the Ministry of Transportation of Quebec. However, some cost savings can be made for the SM soils in zone 3 because of the higher air freezing index. Nevertheless, the benefits in this case are the lowest encountered among the others considered.

\subsection{Assessment of the relative damage}

In order to verify the reliability of the proposed approach to adjust the air freezing index in terms of pavement performance, a comparative analysis of pavement deterioration (assessed in terms of road roughness) was carried out between identical pavement structures. This was done using the previously developed relationship between the observed frost heave and the annual roughness deterioration. The pavement structures considered are the same as the ones 
presented in section 3.2, which are the pavements designed with $\mathrm{Fl}_{\mathrm{a}}$ and $\mathrm{Fl}_{\mathrm{a} \text {-adj, }}$, respectively. For national roads, the period 2010-2040 was considered, while the period 2010-2035 was considered for regional and local roads (Table 2). For the pavements designed with $\mathrm{Fl}_{\mathrm{a} \text {-adj, }}$ the total damage was obtained from the damage rate, which was determined using the frost heave that occurred in the middle of the design period. This damage rate value was then multiplied by the design life of the pavement structure.

Table 6 presents the results of this analysis. In order to validate the proposed correction approach, the ratio between the sum of the roughness damage for the pavement structures designed with $\mathrm{Fl}_{\mathrm{a}}$ and the sum of the roughness damage for the pavement structures designed with $F l_{\text {a-adj }}$ was calculated. This ratio is expressed as

$$
\operatorname{Ratio}(\%)=100 \frac{\sum \Delta \mathrm{IRI}}{\sum \Delta \mathrm{IRI}_{\mathrm{adj}}}
$$

in which $\Sigma \Delta I R I$ is the sum of roughness damage for the pavements designed with $F I_{\mathrm{a}}$ and $\Sigma \Delta I R I_{\text {adj }}$ is the sum of roughness damage for the pavements designed with $\mathrm{Fl}_{\mathrm{a} \text {-adj. }}$. For adequate interpretation of this analysis, it should be recall that only the pavement structures built on clayey soils and the pavement structure built on an SM subgrade soil show a decreased subbase thickness when the approach for the correction of the air freezing index is used. Ratios lower than $100 \%$ are observed for each pavement functional class of the $C L$ subgrade soil. This means that the roughness damage is slightly higher when the $F l_{\mathrm{a} \text {-adj }}$ is used for the design. The average roughness damage ratio is found to vary between 93.08 and 97.02 for all the zones considered. This is associated with an average total roughness damage of $0.25 \mathrm{~m} \mathrm{~km}^{-1}$ higher when the $\mathrm{Fl}_{\mathrm{a} \text {-adj }}$ 
is used; both damages are therefore very similar. The ratio values are generally higher but close to $100 \%$ for the pavement structures in which the subbase thickness did not have to be adjusted between methods for considering the air freezing index for the pavement design (SM and GCGM subgrade soils). This is related to the fact that, for a given total pavement thickness, the frost heave is lower for the cases where $\mathrm{Fl}_{\mathrm{a} \text {-adj }}$ is used, as it is a lower value than the $\mathrm{Fl}_{\mathrm{a}}$. The corresponding damage is therefore lower. When the subbase thickness varies, this variation is likely to have an impact on the calculated roughness damage ratio. Nevertheless, as presented in Table 6, the calculated roughness damage ratios are all close to $100 \%$, which means that the proposed adjustment method for the air freezing index may be adequate to predict future winter period climate changes. In some cases, the proposed method may lead to some cost benefits associated with a decrease in the subbase thickness.

\section{Conclusion}

Climatic data are necessary inputs for adequate pavement design against frost action in northern environments. The air freezing index is extensively used to describe the length and the severity of the winter period. Considering the expected climate changes over the next few decades, which imply evolving climatic data, and the typical service life of flexible pavement structures, the constantly changing air freezing index should be taken into account in the pavement design process. This paper introduced the results of a comprehensive study to establish a correction method of the air freezing index to take into account future climate changes. The results were presented for a median scenario of greenhouse gases increase. The study allowed concluding that, because of the reduction of the air freezing index in the frost 
protection design inputs, a thickness decrease of about $100 \mathrm{~mm}$ can be considered for the subbase when flexible pavements are built on frost sensitive subgrade soils. The roughness damage ratio was used to quantify the effect of the proposed air freezing index correction method on pavement performance. The proposed method showed an increase of pavement life, quantified with roughness, for most of the cases considered (soil types and road functional class). The roughness damage ratio showed a slight decrease of pavement life of maximum value of about $7 \%$ for roads built on clayey soils.

\section{Acknowledgements}

The authors wish to thank Ouranos, Montreal City and the Ministry of Transportation of Quebec for their financial and technical contribution to the fulfilment of this research project. 


\section{References}

Aldrich, H.P. and Paynter, H.M. 1966. Depth of frost penetration in non-uniform soil. U.S. Army Cold Regions Research Laboratory Special Report 104.

American Association for State Highway and Transportation Officials (AASHTO), 1993. Guide for design of pavement structures. American Association of State Highway Officials.

Andersland, O. B. and Ladanyi, B. 2004. An introduction to frozen ground engineering. John Wiley \& sons.

Armstrong, M.D., and T.I. Csathy, 1963. Frost Design Practice in Canada. Highway Research Record, No. 33, p. 170-201.

Bilodeau, J.-P. and Doré, G. 2013. A new pavement design procedure for frost protection in seasonal frost areas. Bearing Capacity of Roads Railways and Airfields, Trondheim, June 25th to $27^{\text {th }}$, Trondheim, Norway.

Byram, D., Xiao, D. X., Wang, K. C. P., and Hall, K., 2012. Sensitivity Analysis of Climatic Influence on MEPDG Flexible Pavement Performance Prediction. Presented at 91st Annual Meeting of the Transportation Research Board, Washington, D.C., 2012.

Carrera, A., Dawson, A., and Steger, J. 2009. Report N 1: State Of The Art Of Likely Effet Of Climate On Current Roads. ITRB. University Of Nottingham, Nottingham. United Kingdom. 
Chaumont, R.D. and Brown, R.D., 2010. Analyse de simulations régionales du climat et d'indices climatiques associés au transport routier dans le Sud du Québec. Revue Routes - Road, no. 345, premier trimestre 2010, pp. 78-83.

Collins, M., Knutti, R., Arblaster, J., Dufresne, J.-L., Fichefet, T., Friedlingstein, P., Gao, X., Gutowski, W., Johns, T., Krinner, G., Shongwe, M., Tebaldi, C., Weaver, A. and Wehner, M. 2013. Long-term Climate Change: Projections, Commitments and Irreversibility. In: Stocker TF, Qin D, Plattner G-K, Tignor M, Allen SK, Boschung J, Nauels A, Xia Y, Bex V, Midgley PM (eds) Climate Change 2013: The Physical Science Basis Contribution of Working Group I to the Fifth Assessment Report of the Intergovernmental Panel on Climate Change. Cambridge University Press, Cambridge, United Kingdom and New York, NY, USA.

Côté, J. and Konrad, J.-M. 2005. A generalized thermal conductivity model for soils and construction materials. Canadian Geotechnical Journal (42): 443-458.

Dawson, A. 2010. Pavement Performance and Remediation Requirements following Climate Change. Road EraNet, 8 p.

DesJarlais, C., Allard, M., Blondot, A., Bourque, A., Chaumont, D., Gosselin, P., Houle, D., Larrivée, C., Lease, N., Roy, R., Savard, J.-P., Turcotte, R. et Villeneuve, C., 2010. Savoir s'adapter aux changements climatiques. Consortium Ouranos, Montréal, 2010, 130 p. 
Doré, G., and Zubeck, H. K. 2009. Cold Regions Pavement Engineering. American Society of Civil Engineers Press, Reston, VA.

Doré, G. 1997. Détérioration des chaussées en conditions de gel : une nouvelle approche prévisionnelle. PhD dissertation, Université Laval, Québec.

Doré, G. 2002. Validation des modèles de détérioration de la chaussée soumise au soulèvement par le gel (Validation of performance models for pavements subjected to frost heave. Research report GCT-02-07, Civil Engineering Department, Laval University, Quebec City, Canada (in French).

Drolet, F. P. 2015. Effets des changements climatiques sur la performance à long terme des chaussées souples au Québec : Volet 2-Effet de l'augmentation de la température en hiver et d'une hausse du nombre d'épisode de redoux hivernaux. Master thesis, Université Laval, Québec, Canada.

Dysli, M., Lunardini, V. and Stenberg, L. 1997. Related effects on frost action: Freezing and solar radiation indices. Ground freezing 97, Knutsson, S. (ed.). A.A. Balkema, Rotterdam.

Emery, J. 2010. Climate change impacts on asphalt pavements: Global perspective, adaptation and opportunities. Canadian User Producer Group of Asphalt, Canadian Technical Asphalt Association, Edmonton meeting. 
Graves, R. C., and K. C. Mahboub, 2006. Pilot Study in Sampling-Based Sensitivity Analysis of NCHRP Design Guide for Flexible Pavements. In Transportation Research Record: Journal of the Transportation Research Board, No. 1947, Transportation Research Board of the National Academies, Washington, D.C., 2006, pp. 123-135.

Gustavsson, H., E. Slunga and S. Saarelainen, 1999. Finnish frost design concept of roads, Geotechnical engineering for transportation infrastructure. Proceedings of the 12th European conference on soil mechanics and geotechnical engineering, Amsterdam, June 2, p. 1359- 1366.

Huang, Y.H. 2004. Pavement analysis and design. Pearson Prentice Hall, New Jersey.

IPCC, 2007. Contribution of Working Group II to the Fourth Assessment Report of the Intergovernmental Panel on Climate Change. M.L. Parry, O.F. Canziani, J.P. Palutikof, P.J. van der Linden and C.E. Hanson, Eds., Cambridge University Press, Cambridge, UK, 976 pp.

IPCC, 2013. Climate Change 2013: The Physical Science Basis. Contribution of Working Group I to the Fifth Assessment Report of the Intergovernmental Panel on Climate Change [Stocker, T.F., D. Qin, G.-K. Plattner, M. Tignor, S.K. Allen, J. Boschung, A. Nauels, Y. Xia, V. Bex and P.M. Midgley (eds.)]. Cambridge University Press, Cambridge, United Kingdom and New York, NY, USA, 1535 pp.

Kersten, M.S. 1949. Laboratory research for the determination of the thermal properties of soils. Research Laboratory Investigations, Engineering Experiment Station, University of Minnesota, Minneapolis, Minn. Technical Report 23. 
Kim, S., H. Ceylan, and M. Heitzman, 2005. Sensitivity Study of Design Input Parameters for Two Flexible Pavement Systems Using the Mechanistic Empirical Pavement Design Guide. Proceedings Mid-Continent Transportation Research Symposium, University of lowa, Ames.

Konrad, J.-M. and Morgenstern, N.R., 1981. The segregation potential of a freezing soil. Canadian Geotechnical Journal, 18, 482-491.

Konrad, J.-M. and Roy, M. 2000. Flexible pavements in cold regions: a geotechnical perspective. Canadian Geotechnical Journal, 37: 689-699.

Ladanyi, B. 1996. Conception et réhabilitation des infrastructures de transports en régions nordiques. Études et recherches en transports, Rapport RTQ-94-07, Gouvernement du Québec, Ministère des Transports, $123 \mathrm{p}$.

Logan, T., I. Charron, D. Chaumont, D. Houle, 2011. Atlas de scénarios climatiques pour la forêt québécoise. Ouranos et Ministère des Ressources Naturelles et de la Faune, 55p.

Maloney, E. D., Camargo, S. J., Chang, E., Colle, B., Fu, R., Geil, K. L., et al. 2014. North American climate in cmip5 experiments: part iii: assessment of twenty-first-century projections. Journal of Climate, 27(6), 2230-2270. 
Mills, B., Tighe, S.L., Andrey, J., Smith, J. and Huen, K. 2009. Climate change implications for flexible pavement design and performance in southern Canada. Journal of Transportation Engineering, 135(10): pp. 773-782.

Nakicenovic, N., Alcamo, J., Davis, G., De Vries, B., Fenhann, J., Gaffin, S. and Kram, T. 2000. Special report on emissions scenarios, working group III, Intergovernmental Panel on Climate Change (IPCC), Cambridge University Press, Cambridge, 559 p.

NCHRP 2004. Guide for Mechanistic-Empirical Design of New and Rehabilitated Pavement Structures. Final Report, NCHRP Project 1-37A. TRB, National Research Council, Washington, D.C.

Saarelainen, S. 1992. Modelling frost heaving and frost penetration in soils at some observation sites in Finland: The SSR model. Espoo 1992, VTT, VTT publications 95, Technical research centre of Finland, $120 \mathrm{p}$.

Saint-Laurent, D. 2006. CHAUSSÉE2 - Logiciel de dimensionnement des chaussées souples: guide de l'utilisateur. Service des chaussées, Direction du laboratoire des chaussées, Ministère des Transports du Québec, 78 p.

Saint-Laurent, D. 2012. Routine Mechanistic Pavement Design against Frost Heave. Cold Regions Engineering 2012: Sustainable Infrastructure Development in a Changing Cold Environment, Quebec City, August 2012, pp:144-154. 
Solomon, S., Qin, D., Manning ,M., Chen, Z., Marquis, M., Averyt, K.B., Tignor, M., Miller, H.L., 2007. Climate Change 2007: The Physical Science Basis. IPCC International Panel on Climate Change, Cambridge University Press, Cambridge, United Kingdom and New York, NY, USA, 996 pp.

TAC, 1997. Pavement design and management guide. Edited by R. Haas. Transportation Association of Canada, Waterloo, Ont.

Tammirinne, M., Valkeisenmäki, A. and Ehrola, E. 2002. Road structures research program 19942001. Summary report, Finnra Reports 37/2002, Finnish Road Administration, Helsinki, Finland.

Thiam, P. M., Doré, G. and Bilodeau, J.-P. 2013. Effect of the future increases of precipitation on the long-term performance of roads. Bearing Capacity of Roads Railways and Airfields, Trondheim, June 25th to 27 th.

Thiam, P. M. 2014. Effets des futurs changements climatiques sur la performance à long terme des chaussées souples au Québec. Master thesis, Université Laval, Québec, Canada.

Tighe, S. L., Smith, J., Mills, B. and Andrey, J. 2008. Evaluating Climate Change Impact on LowVolume Roads in Southern Canada. Transportation Research Record: Journal of the Transportation Research Board, No 2053, Transportation Research Board of the National Academies, Washington D.C., 2008, pp. 9-16. 
Table 1. Rate of decreasing air freezing index with respect to time for the three climatic zones

\begin{tabular}{ccc}
\hline Zone & $\boldsymbol{F l}_{\mathrm{a}}$ decreasing rate $\left({ }^{\circ} \mathrm{C} * \mathrm{~d}^{*} \mathrm{yr}^{-1}\right)$ & $\mathbf{R}^{2}$ \\
\hline 1 & -7.764 & 0.996 \\
2 & -8.219 & 0.967 \\
3 & -9.656 & 0.996 \\
\hline
\end{tabular}

Table 2. Design objectives for the pavement functional classes considered

\begin{tabular}{|c|c|c|c|c|}
\hline Pavement class & $\begin{array}{c}\text { Traffic class } \\
\text { MADT }^{*}\left(\text { vehicle } d^{-1}\right)\end{array}$ & $\begin{array}{c}\text { Design life } \\
\text { (year) }\end{array}$ & $\begin{array}{l}\text { ESALs* } \\
\left(\times 10^{6}\right)\end{array}$ & $\begin{array}{c}\text { Allowable frost } \\
\text { heave }(\mathrm{mm})\end{array}$ \\
\hline National & $5000-20000$ & 30 & 5 & 55 \\
\hline Regional & $2000-3000$ & 25 & 2 & 60 \\
\hline Local & $<1000$ & 25 & 0.5 & 70 \\
\hline
\end{tabular}

*MADT = Mean Annual Daily Traffic; ESAL = Equivalent Single Axle Load

Table 3. Subgrade soil properties used for structural and frost protection design

\begin{tabular}{|c|c|c|c|c|c|c|c|}
\hline Soil type & $\begin{array}{c}\text { Mreff } \\
\mathrm{MPa}\end{array}$ & $\begin{array}{c}\boldsymbol{S P}_{\mathbf{0}} \\
\mathrm{mm}^{2}{ }^{\circ} \mathrm{K}^{-1} \cdot \mathrm{h}^{-1}\end{array}$ & $\begin{array}{c}\boldsymbol{a} \\
\mathrm{MPa}^{-1}\end{array}$ & $\underset{\mathrm{Kg} \mathrm{m}^{-3}}{\rho_{\mathrm{d}}}$ & $\mathrm{J} \mathrm{s}^{-1} \mathrm{~m}^{-1}{ }^{\circ} \mathrm{K}^{-1}$ & $\begin{array}{l}S_{r} \\
\%\end{array}$ & $\begin{array}{c}L_{f} \\
W h m^{-3}\end{array}$ \\
\hline$C L\left(I_{p}<12\right.$ and $\left.\left.I_{L}<0.9\right)\right)$ & 36 & 5.0 & 10.0 & 1300 & 2.29 & 99 & 42265 \\
\hline $\operatorname{SM}\left(P_{80 \mu \mathrm{m}}>30 \%\right) *$ & 45 & 4.0 & 11.0 & 1800 & 2.39 & 82 & 21802 \\
\hline GC-GM & 87 & 2.0 & 15 & 1800 & 2.14 & 79 & 21519 \\
\hline
\end{tabular}

* $P_{80 \mu \mathrm{m}}>30 \%$ : percentage of particles finer than $80 \mu \mathrm{m}$ lower than $30 \%$

Table 4. Pavement designs for each case considered for the reference year using the normal air freezing index

\begin{tabular}{ccccc}
\hline \multirow{2}{*}{ Road type } & Layer & \multicolumn{3}{c}{$\begin{array}{c}\text { Layer thickness (mm) } \\
\text { Soil type : CL / SM / GC-GM }\end{array}$} \\
\cline { 3 - 5 } & & Zone 1 & Zone 2 & Zone 3 \\
\cline { 3 - 5 } National & AC & $170 / 170 / 170$ & $170 / 170 / 170$ & $170 / 170 / 170$ \\
& Base & $250 / 250 / 250$ & $250 / 250 / 250$ & $250 / 250 / 250$ \\
& Subbase & $850 / 300 / 300$ & $1025 / 300 / 325$ & $1725 / 700 / 300$ \\
\hline \multirow{2}{*}{ Regional } & AC & $130 / 130 / 130$ & $130 / 130 / 130$ & $130 / 130 / 130$ \\
& Base & $225 / 225 / 225$ & $225 / 225 / 225$ & $225 / 225 / 225$ \\
& Subbase & $875 / 300 / 300$ & $1050 / 300 / 300$ & $1725 / 650 / 300$ \\
\hline \multirow{2}{*}{ Local } & AC & $90 / 90 / 900$ & $90 / 90 / 900$ & $90 / 90 / 900$ \\
& Base & $200 / 200 / 200$ & $200 / 200 / 200$ & $200 / 200 / 200$ \\
& Subbase & $825 / 300 / 300$ & $1000 / 300 / 300$ & $1650 / 450 / 300$
\end{tabular}


Table 5. Analysis of the economy in subbase granular materials using the adjusted air freezing index

\begin{tabular}{|c|c|c|c|c|c|c|c|c|}
\hline \multirow[b]{2}{*}{ Zone } & \multirow[b]{2}{*}{ Soil type } & \multirow[b]{2}{*}{ Pavement class } & \multicolumn{2}{|c|}{$F I_{a}$} & \multicolumn{4}{|c|}{$F I_{\text {a-adj }}$} \\
\hline & & & $\begin{array}{c}D_{\mathrm{sb}} \\
(\mathrm{mm})\end{array}$ & $\begin{array}{l}h^{*} \\
(\mathrm{~m})\end{array}$ & $\begin{array}{c}D_{\mathrm{sb}} \\
(\mathrm{mm})\end{array}$ & $\begin{array}{l}h_{\mathrm{av}}{ }^{*} \\
(\mathrm{~m})\end{array}$ & $\begin{array}{l}\Delta D_{\mathrm{sb}} \\
(\mathrm{mm})\end{array}$ & $\begin{array}{c}\text { Economy } \\
\left(\$ \mathrm{~m}^{-2}\right)\end{array}$ \\
\hline \multirow{9}{*}{1} & \multirow{3}{*}{$\mathrm{CL}$} & National & 850 & 0.055 & 725 & 0.055 & 125 & 1.125 \\
\hline & & Regional & 875 & 0.059 & 775 & 0.059 & 100 & 0.900 \\
\hline & & Local & 825 & 0.070 & 725 & 0.070 & 100 & 0.900 \\
\hline & \multirow{3}{*}{ SM } & National & 300 & 0.048 & 300 & 0.044 & 0 & 0 \\
\hline & & Regional & 300 & 0.051 & 300 & 0.048 & 0 & 0 \\
\hline & & Local & 300 & 0.055 & 300 & 0.052 & 0 & 0 \\
\hline & \multirow{3}{*}{ GC-GM } & National & 300 & 0.022 & 300 & 0.021 & 0 & 0 \\
\hline & & Regional & 300 & 0.024 & 300 & 0.023 & 0 & 0 \\
\hline & & Local & 300 & 0.026 & 300 & 0.025 & 0 & 0 \\
\hline \multirow{9}{*}{2} & \multirow{3}{*}{$\mathrm{CL}$} & National & 1025 & 0.055 & 900 & 0.055 & 125 & 1.125 \\
\hline & & Regional & 1050 & 0.060 & 950 & 0.060 & 100 & 0.900 \\
\hline & & Local & 1000 & 0.070 & 900 & 0.070 & 100 & 0.900 \\
\hline & \multirow{3}{*}{ SM } & National & 300 & 0.053 & 300 & 0.049 & 0 & 0 \\
\hline & & Regional & 300 & 0.056 & 300 & 0.053 & 0 & 0 \\
\hline & & Local & 300 & 0.060 & 300 & 0.057 & 0 & 0 \\
\hline & \multirow{3}{*}{ GC-GM } & National & 300 & 0.025 & 300 & 0.023 & 0 & 0 \\
\hline & & Regional & 300 & 0.027 & 300 & 0.025 & 0 & 0 \\
\hline & & Local & 300 & 0.028 & 300 & 0.027 & 0 & 0 \\
\hline \multirow{9}{*}{3} & \multirow{3}{*}{$\mathrm{CL}$} & National & 1725 & 0.055 & 1625 & 0.055 & 100 & 0.900 \\
\hline & & Regional & 1725 & 0.060 & 1650 & 0.060 & 75 & 0.675 \\
\hline & & Local & 1650 & 0.069 & 1575 & 0.069 & 75 & 0.675 \\
\hline & \multirow{3}{*}{ SM } & National & 675 & 0.055 & 600 & 0.055 & 75 & 0.675 \\
\hline & & Regional & 625 & 0.060 & 550 & 0.060 & 75 & 0.675 \\
\hline & & Local & 450 & 0.070 & 375 & 0.070 & 75 & 0.675 \\
\hline & \multirow{3}{*}{ GC-GM } & National & 300 & 0.032 & 300 & 0.031 & 0 & 0 \\
\hline & & Regional & 300 & 0.034 & 300 & 0.033 & 0 & 0 \\
\hline & & Local & 300 & 0.035 & 300 & 0.034 & 0 & 0 \\
\hline
\end{tabular}

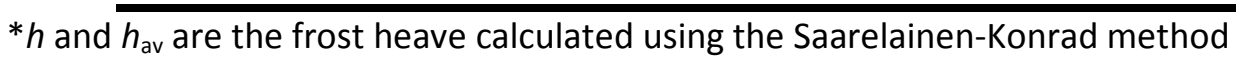


Table 6. Roughness damage ratio for normal and adjusted air freezing index

\begin{tabular}{|c|c|c|c|c|c|c|c|c|c|}
\hline \multirow[b]{2}{*}{ Zone } & \multirow[b]{2}{*}{ Soil } & \multirow[b]{2}{*}{ Pavement class } & \multirow{2}{*}{\multicolumn{2}{|c|}{$\begin{array}{c}F I_{\mathrm{a}} \\
\begin{array}{c}\Sigma \Delta I R \\
\left(\mathrm{~m} \mathrm{~km}^{-1}\right)\end{array}\end{array}$}} & \multicolumn{5}{|c|}{$F I_{\text {a-adj }}$} \\
\hline & & & & & $\begin{array}{c}\Delta I R I_{\mathrm{adj}} \\
\left(\mathrm{m} \mathrm{km}^{-1} \mathrm{yr}^{-1}\right)\end{array}$ & $\begin{array}{l}\sum \Delta I R I_{\text {adj }} \\
\left(\mathrm{m} \mathrm{km}^{-1}\right)\end{array}$ & $\begin{array}{l}\sum \Delta I R l_{\text {adj }} \\
\left(\mathrm{mkm}^{-1}\right)\end{array}$ & $\begin{array}{l}\text { Rat } \\
\text { (\% }\end{array}$ & \\
\hline \multirow{9}{*}{1} & \multirow{3}{*}{$\mathrm{CL}$} & National (30 yrs) & 3.35 & & 0.12 & 3.70 & & 90.6 & \\
\hline & & Regional (25 yrs) & 3.07 & 3.32 & 0.13 & 3.25 & 3.56 & 94.5 & 93.3 \\
\hline & & Local (25 yrs) & 3.53 & & 0.15 & 3.72 & & 94.9 & \\
\hline & \multirow{3}{*}{ SM } & National (30 yrs) & 3.21 & & 0.11 & 3.14 & & 102.5 & \\
\hline & & Regional (25 yrs) & 2.89 & 3.05 & 0.11 & 2.78 & 2.96 & 103.7 & 103.1 \\
\hline & & Local (25 yrs) & 3.04 & & 0.12 & 2.95 & & 103.1 & \\
\hline & \multirow{3}{*}{ GC-GM } & National (30 yrs) & 2.02 & & 0.065 & 1.96 & & 103.2 & \\
\hline & & Regional (25 yrs) & 1.79 & 1.89 & 0.069 & 1.72 & 1.83 & 103.9 & 103.5 \\
\hline & & Local (25 yrs) & 1.87 & & 0.072 & 1.81 & & 103.4 & \\
\hline \multirow{9}{*}{2} & \multirow{3}{*}{$\mathrm{CL}$} & National (30 yrs) & 3.37 & & 0.12 & 3.70 & & 91.3 & \\
\hline & & Regional (25 yrs) & 3.08 & 3.32 & 0.13 & 3.29 & 3.57 & 93.5 & 93.1 \\
\hline & & Local (25 yrs) & 3.51 & & 0.15 & 3.72 & & 94.5 & \\
\hline & \multirow{3}{*}{ SM } & National (30 yrs) & 3.49 & & 0.11 & 3.39 & & 103.0 & \\
\hline & & Regional ( 25 yrs) & 3.13 & 3.30 & 0.12 & 3.00 & 3.18 & 104.3 & 103.6 \\
\hline & & Local (25 yrs) & 3.27 & & 0.13 & 3.17 & & 103.5 & \\
\hline & \multirow{3}{*}{ GC-GM } & National (30 yrs) & 2.15 & & 0.07 & 2.06 & & 104.1 & \\
\hline & & Regional (25 yrs) & 1.89 & 2.00 & 0.07 & 1.81 & 1.92 & 104.8 & 104.3 \\
\hline & & Local (25 yrs) & 1.96 & & 0.08 & 1.89 & & 103.9 & \\
\hline \multirow{9}{*}{3} & \multirow{3}{*}{$\mathrm{CL}$} & National (30 yrs) & 3.51 & & 0.12 & 3.70 & & 94.8 & \\
\hline & & Regional (25 yrs) & 3.21 & 3.45 & 0.13 & 3.29 & 3.55 & 97.4 & 97.0 \\
\hline & & Local (25 yrs) & 3.63 & & 0.15 & 3.68 & & 98.8 & \\
\hline & \multirow{3}{*}{ SM } & National (30 yrs) & 3.62 & & 0.12 & 3.70 & & 97.8 & \\
\hline & & Regional (25 yrs) & 3.27 & 3.54 & 0.13 & 3.29 & 3.57 & 99.2 & 99.2 \\
\hline & & Local (25 yrs) & 3.74 & & 0.15 & 3.72 & & 100.7 & \\
\hline & \multirow{3}{*}{ GC-GM } & National (30 yrs) & 2.54 & & 0.08 & 2.47 & & 102.6 & \\
\hline & & Regional (25 yrs) & 2.21 & 2.34 & 0.09 & 2.15 & 2.27 & 103.0 & 103.2 \\
\hline & & Local (25 yrs) & 2.28 & & 0.09 & 2.19 & & 104.2 & \\
\hline
\end{tabular}




\section{Figures list}

Figure 1. Climatic zones considered

Figure 2. Decreasing air freezing index with climatic horizon

Figure 3. Evolution of frost penetration $(X)$, frost heave $(h)$ and yearly rate of roughness increase $(\Delta I R I)$ with respect to time for 3 pavement functional classes and three climatic zones - Example for $\mathrm{CL}$ soil

Figure 4. Adjustment of the air freezing index 


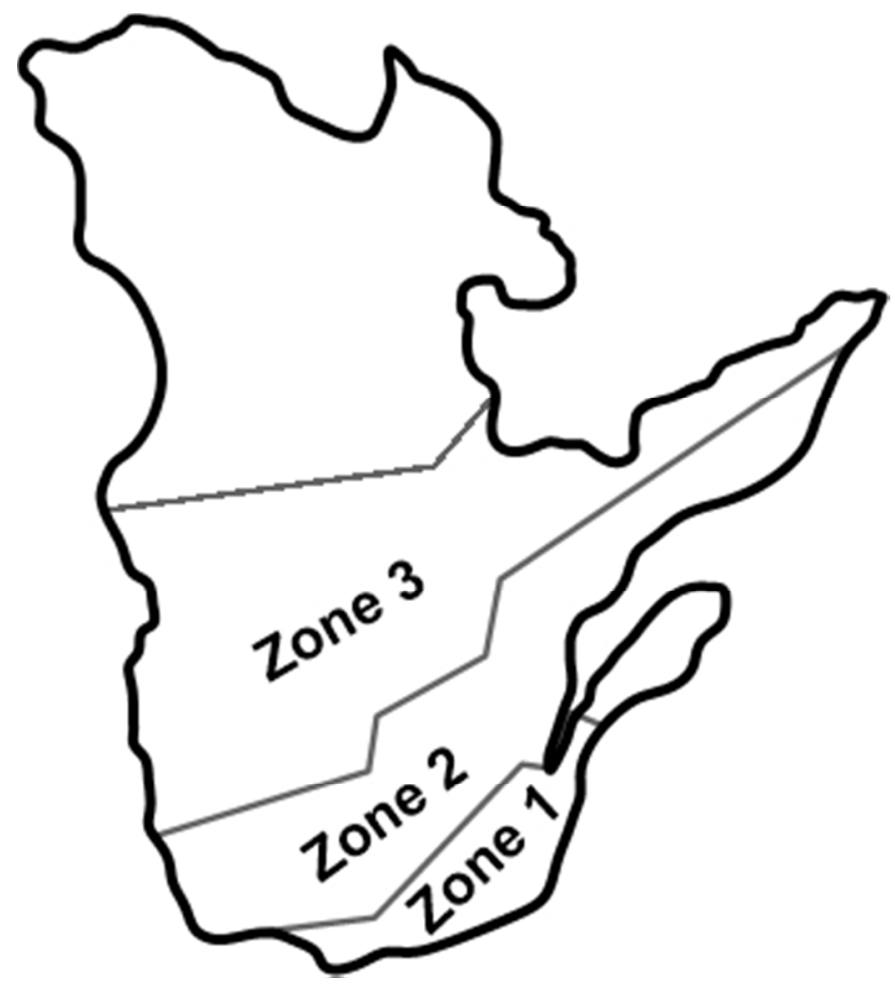

Climatic zones considered $42 \times 46 \mathrm{~mm}$ ( $200 \times 200$ DPI) 


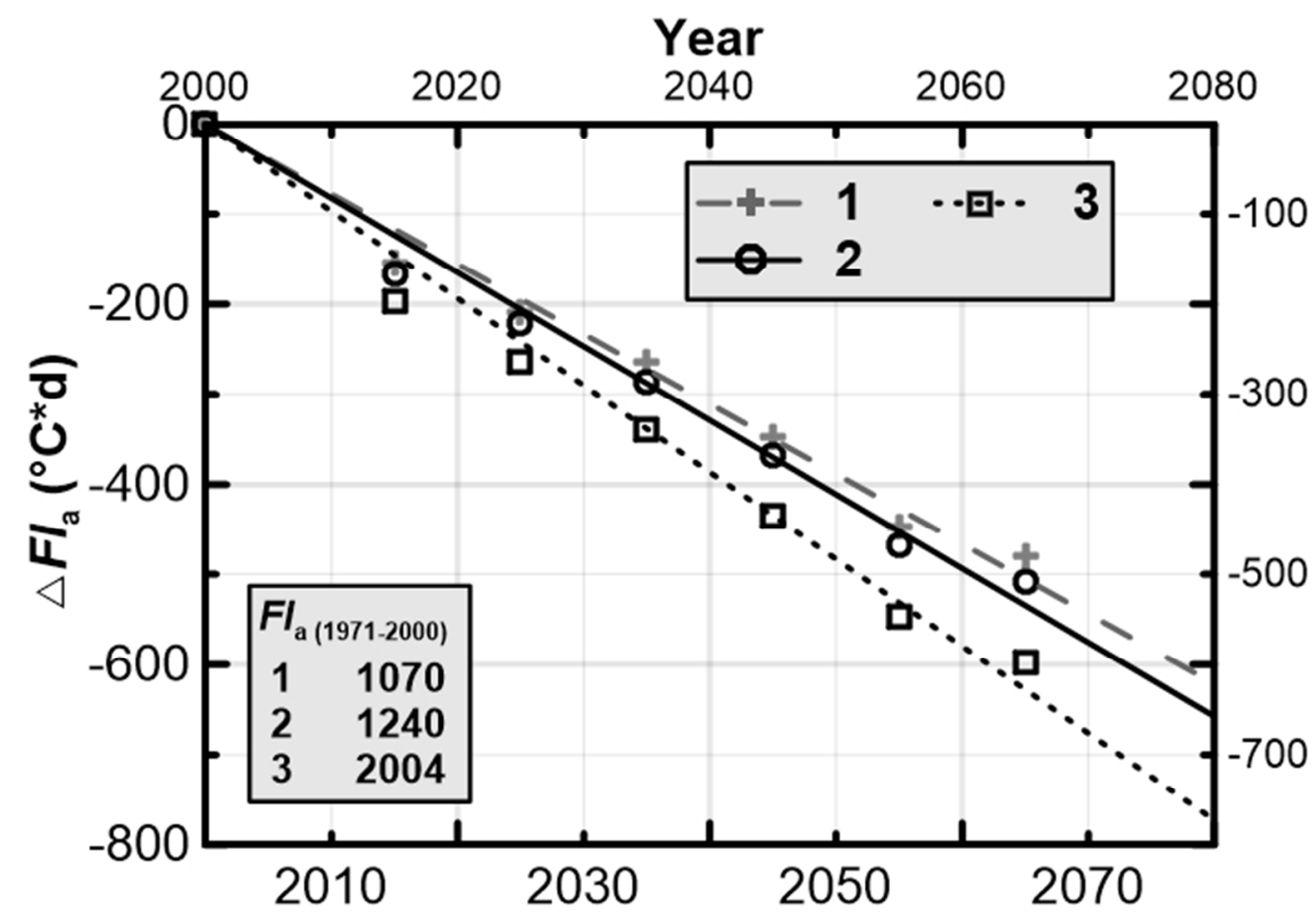

Decreasing air freezing index with climatic horizon $89 \times 62 \mathrm{~mm}(200 \times 200$ DPI $)$ 

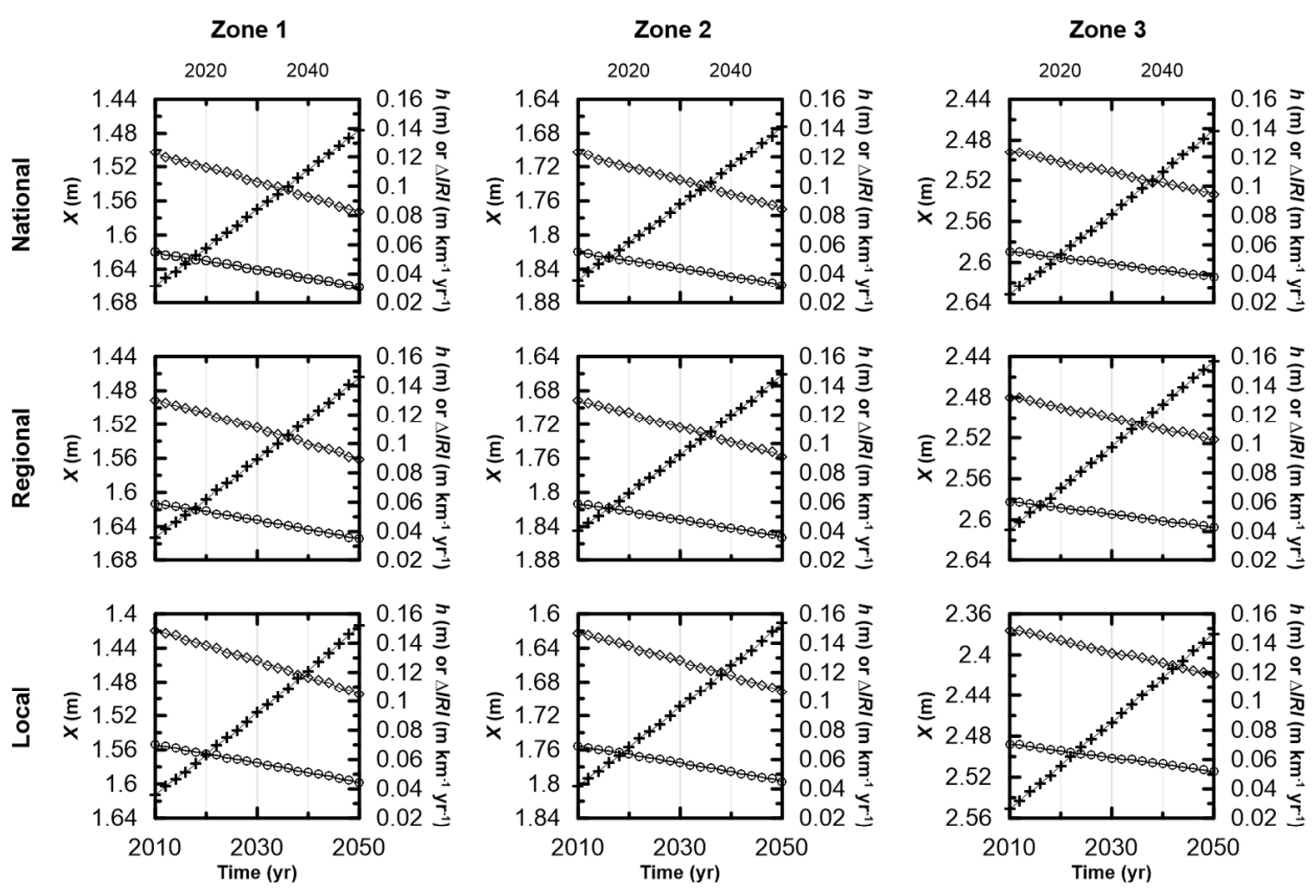

$+++X \quad 0 \quad 0 \quad 0 h \quad \diamond \Delta I R I$

$191 \times 138 \mathrm{~mm}(200 \times 200$ DPI $)$ 


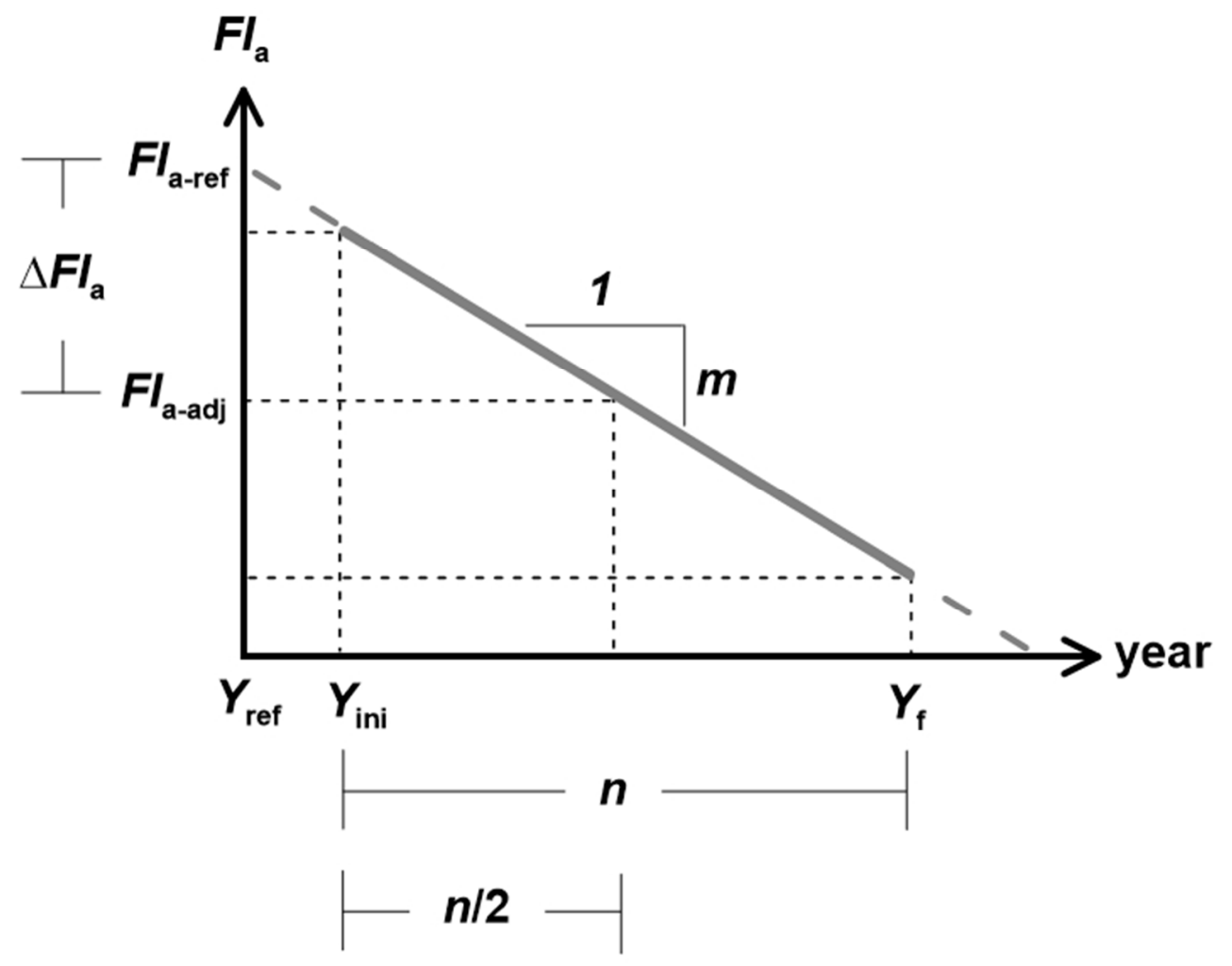

Adjustment of the air freezing index $92 \times 72 \mathrm{~mm}(200 \times 200$ DPI $)$ 